\title{
Identifying urban sources as cause of elevated grass pollen concentrations using GIS and remote sensing
}

\author{
C. A. Skjøth ${ }^{1,2}$, P. V. Ørby ${ }^{3}$, T. Becker ${ }^{2}$, C. Geels ${ }^{2}$, V. Schlünssen ${ }^{3}$, T. Sigsgaard ${ }^{3}$, J. H. Bønløkke ${ }^{3}$, J. Sommer ${ }^{4}$, \\ P. Søgaard ${ }^{5}$, and O. Hertel ${ }^{2,6}$ \\ ${ }^{1}$ Department of Physical Geography and Ecosystems Science, Sölvegatan 12, Lund University, 22362 Lund, Sweden \\ ${ }^{2}$ Department of Environmental Science, Aarhus University, P.O. Box 358, Frederiksborgvej 399, 4000 Roskilde, Denmark \\ ${ }^{3}$ Department of Public Health, Aarhus University, Bartholins Allé 2, 8000 Aarhus C, Denmark \\ ${ }^{4}$ Asthma and Allergy Association Denmark, Universitetsparken 4, 4000 Roskilde, Denmark \\ ${ }^{5}$ Department of Nature and Environment, Municipality of Aarhus, P.O. Box 79, Valdemarsgade 18, 8100 Aarhus, Denmark \\ ${ }^{6}$ Department for Environmental, Social and Spatial Change (ENSPAC), Roskilde University, P.O. Box 260, Universitetsvej 1, \\ 4000 Roskilde, Denmark
}

Correspondence to: C. A. Skjøth (c.skjoth@worc.ac.uk)

Received: 26 September 2012 - Published in Biogeosciences Discuss.: 16 October 2012

Revised: 17 December 2012 - Accepted: 24 December 2012 - Published: 29 January 2013

\begin{abstract}
We examine here the hypothesis that during flowering, the grass pollen concentrations at a specific site reflect the distribution of grass pollen sources within a few kilometres of this site. We perform this analysis on data from a measurement campaign in the city of Aarhus (Denmark) using three pollen traps and by comparing these observations with a novel inventory of grass pollen sources. The source inventory is based on a new methodology developed for urbanscale grass pollen sources. The new methodology is believed to be generally applicable for the European area, as it relies on commonly available remote sensing data combined with management information for local grass areas. The inventory has identified a number of grass pollen source areas present within the city domain. The comparison of the measured pollen concentrations with the inventory shows that the atmospheric concentrations of grass pollen in the urban zone reflect the source areas identified in the inventory, and that the pollen sources that are found to affect the pollen levels are located near or within the city domain. The results also show that during days with peak levels of pollen concentrations there is no correlation between the three urban traps and an operational trap located just $60 \mathrm{~km}$ away. This finding suggests that during intense flowering, the grass pollen concentration mirrors the local source distribution and is thus a local-scale phenomenon. Model simulations aimed at assessing population exposure to pollen levels are therefore rec-
\end{abstract}

ommended to take into account both local sources and local atmospheric transport, and not to rely only on describing regional to long-range transport of pollen. The derived pollen source inventory can be entered into local-scale atmospheric transport models in combination with other components that simulate pollen release in order to calculate urban-scale variations in the grass pollen load. The gridded inventory with a resolution of $14 \mathrm{~m}$ is therefore made available as supplementary material to this paper, and the verifying grass pollen observations are additionally available in tabular form.

\section{Introduction}

Grass pollen is the most widespread pollen allergen in Europe (Emberlin et al., 1999, 2000; Jato et al., 2009; Laaidi, 2001; Smith et al., 2009), and furthermore grass pollen allergy is the most frequent pollen allergy in Europe (D'amato et al., 2007; WHO, 2003). Atmospheric concentrations of grass pollen are commonly forecasted and published in order to facilitate self-care among grass pollen allergic subjects. The forecasting of grass pollen concentrations is generally done with statistical models (Chuine and Belmonte, 2004; Garcìa-Mozo et al., 2009; Laaidi, 2001; Smith and Emberlin, 2005, 2006). Statistical or empirical forecast models are, by their nature, limited to the area where they are produced 
(Stach et al., 2008). Whether this area covers only the specific urban area where the pollen trap is placed or the area has a larger geographical extent is usually unknown.

Urban areas have previously been reported to be important sources of birch (Betula) pollen in the urban environment. Here parks, gardens and small woodlands are considered an important source of increased birch pollen concentrations within the city (Skjøth et al., 2008b). Similar to birch trees, grass areas are commonly found in or near urban areas (Pauleit and Duhme, 2000a). Grass pollen grains from wild grass species usually have a size of $30-40 \mu \mathrm{m}$ in diameter (Brown and Irving, 1973) and about 50-60 $\mu \mathrm{m}$ for the crop rye (Durham, 1946), whereas birch pollen is only about $20 \mu \mathrm{m}$ in diameter (Mäkelä, 1996). Both grass and birch pollen are nearly spherical and must be expected to have a density slightly less than water (Gregory, 1973). Hence, according to Stokes' law, grass pollen has a settling velocity which is about four times larger than the settling velocity of birch pollen, which is about $1 \mathrm{~cm} \mathrm{~s}^{-1}$ (Skjøth et al., 2007; Sofiev et al., 2006a), resulting in shorter suspension time in the atmosphere for grass pollen.

Grass pollen is released just above ground level. This also differs from the case of birch pollen where the release height is $5-25 \mathrm{~m}$ above ground. An increased release height of an air pollutant will in general decrease the concentration near the source but widen the footprint area (Seinfeld and Pandis, 1998), and this principle also applies to the pollen distribution in the atmosphere. Figure 1 illustrates this principle by displaying the calculated pollen concentration near a source, using the Gaussian principle. The source is set to emit 1 million pollen grains - amounts that are commonly found in grasses, trees and weeds: rye (Secale), birch (Betula) and ragweed (Ambrosia) (Fumanal et al., 2007; Pohl, 1937). Grass pollen thus has a larger settling velocity and lower release height compared to birch pollen, and as a result the difference between surface and rooftop concentrations for grass pollen is much higher that the difference found for birch pollen, which has also been documented in experiments (Alcazar et al., 1999; Rantio-Lehtimaki et al., 1991). Consequently, two hypotheses can be formulated:

- The low release height, the large surface/rooftop variations and the potential presence of grass pollen sources in or near the urban area suggest that large intra-urban variations will be present for grass pollen in the air.

- Intra urban variations in grass pollen concentrations are linked to local-scale variations in source distribution.

We will investigate these two hypotheses individually with use of the following three components:

- A dedicated intra-urban grass pollen measurement campaign for the pollen season 2009.

- Mapping the potential source areas using remote sensing and GIS.

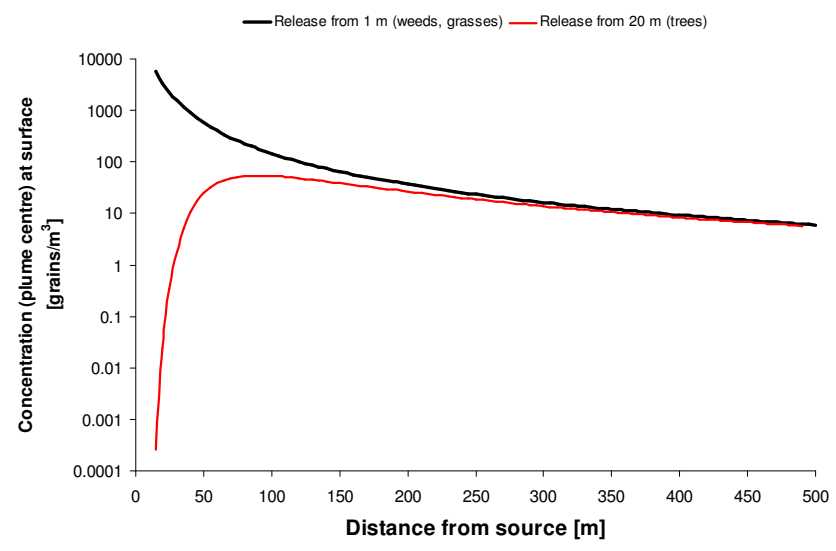

Fig. 1. Local-scale concentration profile of the pollen near the surface after the release of 1 mio pollen grains from trees $(20 \mathrm{~m})$ and weeds/grasses $(1 \mathrm{~m})$. Overall concentration is calculated using neutral meteorological conditions and a wind speed of $5 \mathrm{~m} \mathrm{~s}^{-1}$.

- Linking the source map with possible local air mass transport by using measured wind directions.

\section{Methodology}

\subsection{Pollen data}

In this study we investigated the measured pollen concentrations from three pollen traps in the city of Aarhus, Denmark (Fig. 2). In the southern part of Aarhus, sampling was performed from the roof of the school Rundhøjskolen $\left(56^{\circ} 20^{\prime} \mathrm{N}\right.$, $\left.10^{\circ} 30^{\prime} \mathrm{E}\right), 60 \mathrm{~m}$ above sea level. In the central part of the city, sampling was performed at the Department of Environmental Science (14 m above sea level), Aarhus University's urban background air quality monitoring station in Aarhus - formerly the NERI station (National Environmental Research Institute) (Ellermann et al., 2007). This site also includes measurements of temperature, precipitation, wind speed and direction. In the northern part of the city, sampling was performed at the top of the TV station building, TV2-Østjylland $\left(56^{\circ} 32^{\prime} \mathrm{N}, 10^{\circ} 31^{\prime} \mathrm{E}\right), 75 \mathrm{~m}$ above sea level. The heights of the buildings are $15-20 \mathrm{~m}$, and the surroundings of each of the pollen traps are in general urban (Fig. 2). Additionally, the measured pollen data are compared with data from the operational trap in Viborg, about $60 \mathrm{~km}$ to the north-west (Sommer and Rasmussen, 2009).

Continuous monitoring of pollen content in the air was carried out using a Burkhard volumetric spore trap of the Hirst design (Hirst, 1952). Air is sucked into the trap at a rate of $10 \mathrm{~L} \mathrm{~min}^{-1}$ through a $2 \mathrm{~mm} \times 14 \mathrm{~mm}$ orifice. Behind the orifice, the air flows over a rotating drum that moves past the inlet at $2 \mathrm{~mm} \mathrm{~h}^{-1}$. The drum is covered with an adhesivecoated, transparent plastic tape, which traps the particles. Pollen is identified and counted at $\times 640$ magnification on 12 transverse strips every two hours, according to the method 


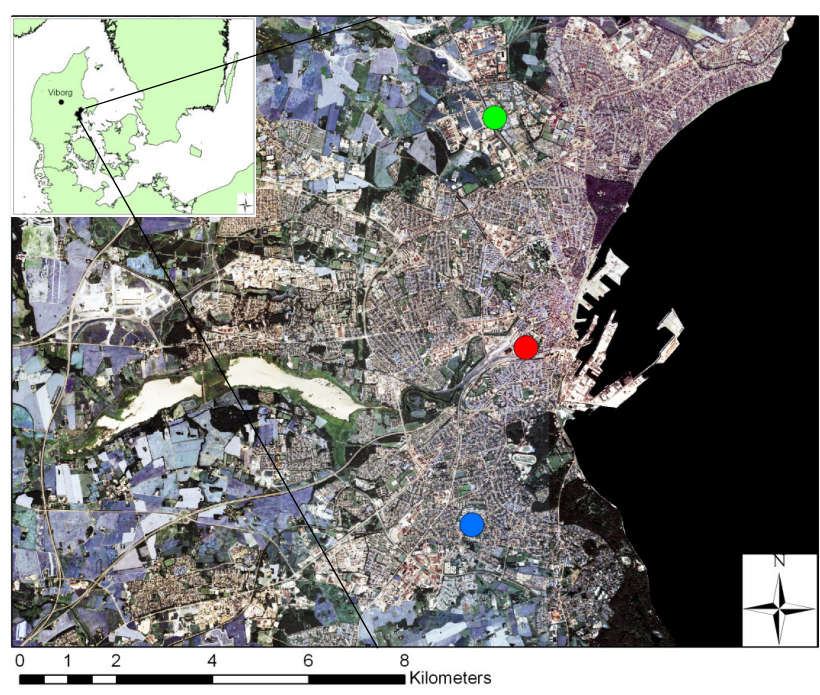

Rundhøjskolen

TV2-Østjylland

Central Aarhus, NERI site

Fig. 2. Municipality of Aarhus, Denmark and location of the three pollen traps in Aarhus and the operational trap in Viborg (upper left).

described by Käpyla and Penttinen (1981). Daily average pollen concentrations are expressed as grains $\mathrm{m}^{-3}$. The total area counted is $65.52 \mathrm{~mm}^{2}$, which is $9.75 \%$ of the total area of the slide, equivalent to the number of pollen grains in $1.44 \mathrm{~m}^{3}$ of air.

\subsection{Remote sensing analysis}

Potential grass pollen source areas in the city of Aarhus are identified using a dataset of six Quickbird satellite images (DigitalGlobe Corporate, 2010) that were taken during summer 2008. The Quickbird satellite images are high resolution datasets (ground resolution of $0.6 \mathrm{~m}$ ) and provide information in four spectral channels (red, green, blue and near infrared) of $2.4 \mathrm{~m}$ ground sample distance (GSD). The $0.6 \mathrm{~m}$ resolution is achieved by the fifth band, which is captured as a panchromatic image (DigitalGlobe Corporate, 2010). The potential grass pollen areas are identified as non-woody, but vegetated areas use the following procedure for land cover classification:

1. Every band of $2.4 \mathrm{~m}$ GSD is combined with the panchromatic channel using image fusion to achieve high spatial and spectral resolution in every channel.

2. Areas covered by lakes and buildings are erased from the dataset to reduce the possibility of false classification.

3. Calculation of the normalized difference vegetation index (NDVI) (Lillesand et al., 2007) for each satellite image is performed using GRASS GIS for image interpretation and image processing (GRASS Development Team, 2008).

4. Grouping NDVI values into three groups: (1) Nonvegetated areas, (2) Woody areas, (3) Non-wooded vegetation areas, where group 3 is used for further analysis.

The final result of this analysis is a $0.6 \mathrm{~m}$ resolution image covering the city of Aarhus and showing the potential grass pollen source areas (Fig. 3). The quality of this NDVI classification has been assessed by an error matrix (Table 2) carried out according to standard methodologies (Lillesand et al., 2007), which in this case separates a limited number of pixels into grass and no grass areas (buildings, lakes, streets and trees).

\subsection{GIS analysis}

In Denmark the grass pollen season usually extends from May to September (Sommer and Rasmussen, 2009), and it is anticipated that up to 100 species may contribute to the overall pollen load. However, for grass species in large parts of Europe, including Denmark, flowering depends on area management. If the grass areas are managed, e.g. cut on a regular basis or heavily grazed by animals, the grass species do not reach maturity - a stage where they can flower. This means that managed areas do not flower - or have very limited flowering. Otherwise, unmanaged grass areas and areas with less frequent management can have grass that flowers. This rule applies for rural as well as urban areas.

Potential areas for possible grass flowering can therefore be identified through analysis of their management. In Denmark one source of information about management is data from the Danish General Agricultural Register (DGAR). DGAR is administered by the Danish Ministry of Food, Agriculture and Fisheries, and includes a map of field areas and data on crop types. Each field area can consist of several minor fields with different crop types. Data are therefore given as a percentage of the field area covered by each crop. The data from 2008 were obtained from DGAR and classified in six groups according to their probability of being a source of grass pollen: (a) fallow, (b) mixed, (c) seedling grasses, (d) permanent grass, (e) rye, and (f) areas without grass (potatoes, sugar beets, etc.).

Management information is also obtained through analysis of a parcel map of Denmark. Each small land parcel (forest, road blocks, detached houses, cemeteries etc.) has its spatial extent mapped in a GIS-based geodatabase at the National Survey and Cadastre. This database is connected to another GIS database, which contains information about location of roads, buildings and land use for the urban environment. This allows for detailed analysis at the parcel level with respect to both structure and land use. Land parcels containing the following features are considered managed or cut on a regular basis: buildings, parks and cemeteries. Land parcels that 


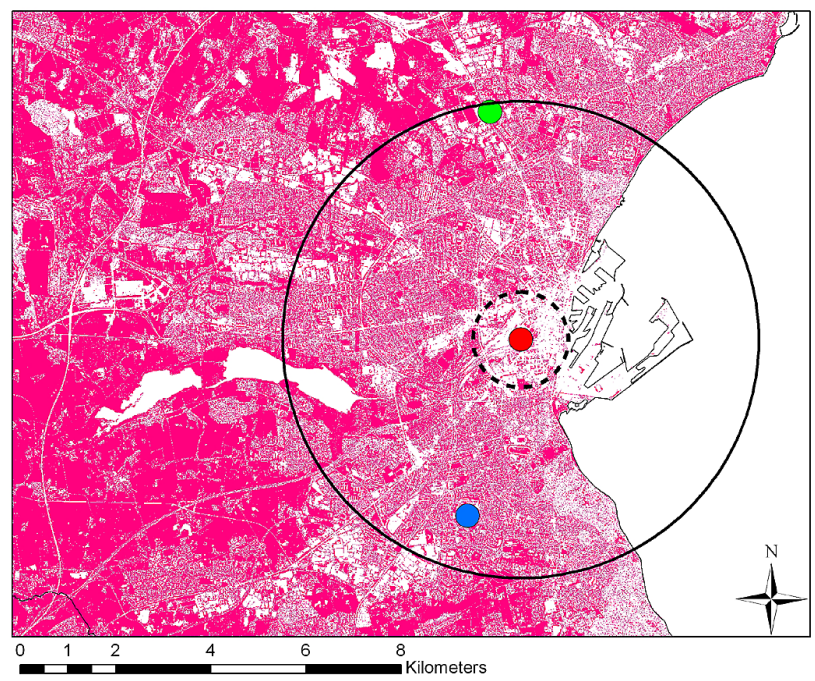

Identified grass areas using NDVI classification method

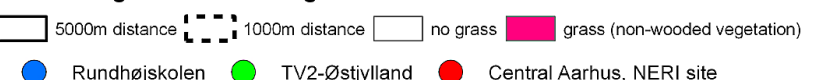

Fig. 3. Possible grass areas in the city of Aarhus based on the NDVI classification methodology described in Sect. 2.2, with a ground resolution of $0.6 \mathrm{~m}$. High density grass areas are displayed as large, intense pink areas and lower density areas as more a of mixture of pink and white pixels. Areas without grass are completely white. Circles are distances from central Aarhus at $1000 \mathrm{~m}$ and $5000 \mathrm{~m}$, respectively.

contain the following features are considered unmanaged: major roads (more than $6 \mathrm{~m}$ wide), rail roads and associated land, construction sites, unmanaged urban or agricultural land and areas without buildings. Finally, an important piece of additional information is that nearly all major public areas are managed by the municipality of Aarhus. The locations of these public areas are known at the parcel level in the GIS system, and these areas also have a known cutting frequency with respect to the management of the grass areas. These public grass areas are cut either annually (1 time), seasonally ( 3 times), monthly or more than 12 times per year, where 12 cuts per year roughly corresponds to a cutting frequency of 2 cuts per month during the grass growing season. Areas with a cutting frequency of 1,3 or 12 cuts per year are considered potential flowering areas, whereas areas with more than 12 cuts per year are considered non-flowering (managed). This information is stored in a management map in the GIS system (Fig. 4). The management map is then converted to a raster data set with the same resolution as the NDVI map (Fig. 3). These two data sets are combined and afterwards aggregated to $14.4 \mathrm{~m}$ resolution by using the mean value of all 576 pixels that are fully contained within each $14.4 \mathrm{~m}$ grid cell (Fig. 8), which shows the major grass pollen flowering areas within and in the vicinity of the city of Aarhus.

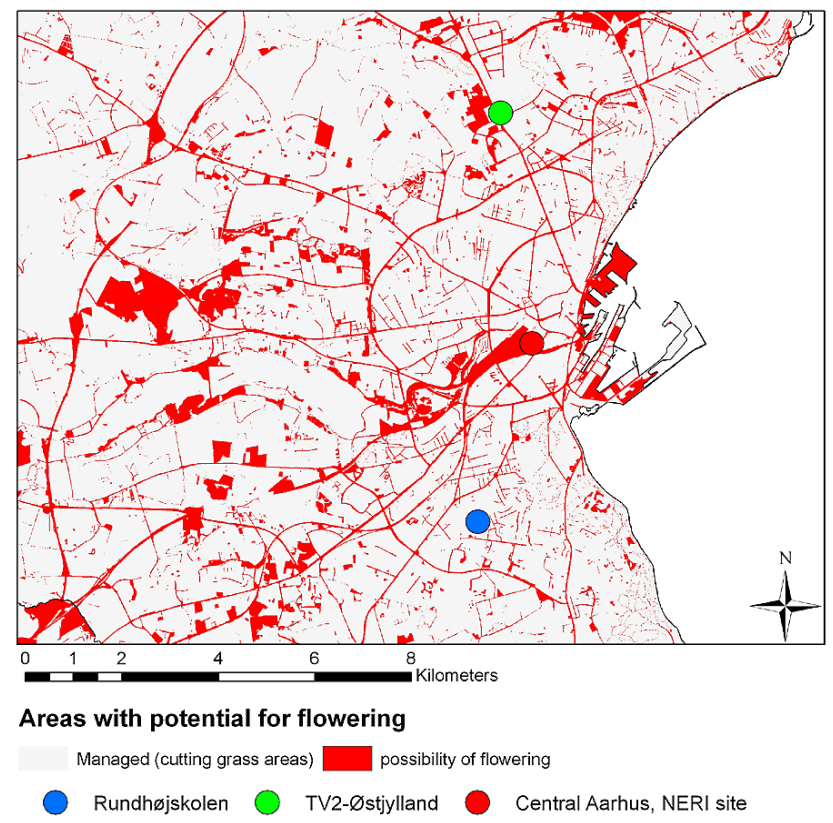

Fig. 4. Flowering possibility according to management criteria of agricultural fields and urban areas according to the method described in Sect. 2.3.

\subsection{Meteorological observations and calculations of wind directions}

Meteorological observations were obtained from the monitoring site in central Aarhus. The meteorological station is part of the monitoring programme operated by the Environmental Science Department and provides meteorological data on a half-hourly basis for use in integrated monitoring of air quality in Denmark (Hertel et al., 2007).

In the analysis, wind directions were used as an indicator of potential upwind source areas, using a similar approach as presented in Skjøth et al. (2009). Wind directions were obtained from $30 \mathrm{~min}$ average raw data for all available grass pollen counts $(n=1.644)$ within the pollen season, i.e. from 25 May till 29 July. For each station, wind directions were sorted by peak days. Peak days are defined as those where the daily average grass pollen count exceeds a threshold of 50 grains $\mathrm{m}^{-3}$. This threshold is based on clinical thresholds at the species level for grass (10 and 50 grains $\mathrm{m}^{-3}$ ), mugwort (10 and 50 grains $\mathrm{m}^{-3}$ ) and birch (30 and 100 grains $\mathrm{m}^{-3}$ ), as defined by Petersen and Munch (1981) and Weeke (1981). The thresholds are furthermore used by the Danish pollen forecasting service, where a daily average level of 50 grains $\mathrm{m}^{-3}$ corresponds to the warning level "high". Days with daily average grass pollen counts $>50$ grains $\mathrm{m}^{-3}$ were gathered and examined as a group for each of the three stations. 


\section{Results}

\subsection{Pollen counts}

The observations and subsequent laboratory studies reveal that the grass pollen season in 2009 started on 25 May and ended on 29 July, using the $95 \%$ method (Goldberg et al., 1988). Table 1 and Fig. 5 show that peak pollen concentrations are observed during the period between 2 June and 5 July. After a slight increase in the pollen concentrations on 2 June, the concentrations show a drop for all locations on 3 and 4 June. The concentrations are highest at all stations during the period 14 June to 5 July, with large day-to-day fluctuations. Maximum values are measured at all stations around 14 to 18 June in the range of $121-237$ grains $^{-3}$ (Table 1), with the highest concentration (TV2-Østjylland: 237 grains $\mathrm{m}^{-3}$ ) occurring on 17 June. The correlation coefficient (Pearson) for the daily pollen counts between each of the stations and the operational trap in Viborg is, for the entire season, between 0.61 and 0.76 . Similarly, the correlation for the peak days is between -0.35 and 0.15 , and for days with pollen concentration up to 50 grains $\mathrm{m}^{-3}$ between 0.68 and 0.88 .

\subsection{Remote sensing NDVI map}

The central urban area corresponding to about $1 \mathrm{~km}$ distance from the measurement station in central Aarhus has very limited grass areas (Fig. 3). A secondary, larger urban part within a distance of $5 \mathrm{~km}$ from the site in central Aarhus shows a medium density of possible grass areas. Several areas show very low or no pollen sources, corresponding to either water surfaces or wooded areas. The error matrix uses 267 control points and shows that there is some confusion between wooded and grass (non-wooded) areas and that the overall accuracy of the classification is $84 \%$ (see Table 2).

\subsection{Flowering map based on management}

Analysis of data from the agricultural registers shows that the six groups had the following distribution: fallow $=5.5 \%$, mixed $=7.1 \%$, seedling grass $=1.6 \%$, permanent grass $=23.2 \%$, rye $=1.9 \%$ and other $=60.6 \%$, respectively. The fallow, seedling grass and rye areas are considered flowering and sources of grass pollen. These areas are usually found scattered outside the urban area, except for a few cases such as near the trap in the northern part of the city. Near the northern trap, agricultural areas with flowering possibility are located to the west of and in close proximity to the urban area (Fig. 4).

The map also shows flowering at a number of long but narrow areas as well as at a few larger areas within the urban area. These areas are mainly associated with large roads, railroad areas, industrial areas and grass areas near streams and wetlands.

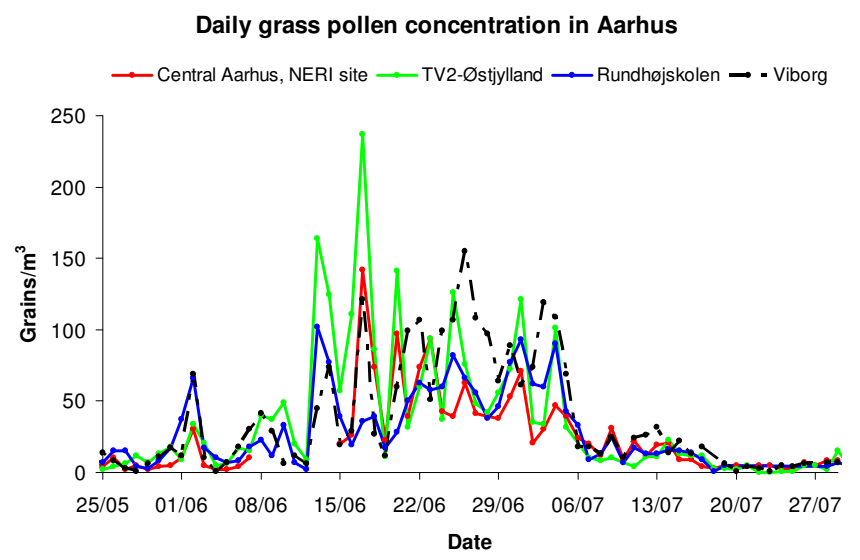

Fig. 5. Daily grass pollen concentrations at the three monitoring sites in Aarhus and the operational pollen trap in Viborg.

\subsection{Meteorological data series}

Figure 6 shows temperature, precipitation and wind directions measured at the central site in Aarhus.

The average night temperature was $13^{\circ} \mathrm{C}$ and the average day temperature was $18^{\circ} \mathrm{C}$ during the campaign period. From the beginning of the campaign period, the temperature gradually rose to maximum daily temperatures of $23^{\circ} \mathrm{C}$ on 2 June. After 2 June a colder period occurred with maximum daily temperatures around $15^{\circ} \mathrm{C}$, which lasted until 24 June, when the temperature again rose during a period through 5 July with maximum temperatures up to $27^{\circ} \mathrm{C}$.

The pollen season period from 25 May to 29 July 2009 had 33 days with precipitation. From 25 May to 21 June there were 4 precipitation episodes each lasting 1-2 days. These rain episodes were followed by a dry period of 13 days which lasted until $5 \mathrm{July}$. After this dry period, it rained almost daily for the remaining part of the period through 29 July.

Wind directions for the entire period (Figs. 6 and 7a) are grouped into main directions, with most of the wind directions in these groups appearing in the sectors $225-270$ and 270-315 degrees. About $10 \%$ arrives from each of the directions 45-90, 90-135, 135-180 and 180-225. Two to five percent arrives from the northerly directions $315-360$ and 045 . Wind directions during peak days for the northern station (TV2-Østjylland station, Fig. 7b) show that for this particular subset $55 \%$ of the winds arrived from sector $270-315$ and almost none from sectors $315-360$ and $0-45$. Wind directions during peak days at the station in central Aarhus (Fig. 7c) show that about $60 \%$ of the time the wind arrives from the two sectors 45-90 and 270-315. The other sectors have a frequency between a few percent and up to $10 \%$. During peak days for the trap at Rundhøjskolen (Fig. 7d), about $40 \%$ of the time the wind is from the west (sector 270-315) and between 5 and $15 \%$ of the time from other sectors. The exception is sector $0-45$ for which there were no observations. 
Table 1. Daily pollen counts in the city of Aarhus and corresponding daily data from the operational monitoring trap in Viborg located $\sim 60 \mathrm{~km}$ away. Numbers in bold exceed the critical threshold for severe hay fever symptoms. Underlined, italicised numbers and "-" mark either a reduced or a missing daily measurement, respectively, due to trap failure.

\begin{tabular}{|c|c|c|c|c|c|c|c|c|c|}
\hline Date & Viborg & $\begin{array}{r}\text { Rundhøj } \\
\text { skolen }\end{array}$ & $\begin{array}{r}\text { TV2- } \\
\text { Østjylland }\end{array}$ & $\begin{array}{l}\text { Aarhus } \\
\text { Centre }\end{array}$ & Date & Viborg & $\begin{array}{r}\text { Rundhøj } \\
\text { skolen }\end{array}$ & $\begin{array}{r}\text { TV2- } \\
\text { Østjylland }\end{array}$ & $\begin{array}{l}\text { Aarhus } \\
\text { Centre }\end{array}$ \\
\hline $25 / 5$ & 14 & 7 & $\underline{2}$ & 4 & $27 / 6$ & 108 & 56 & 48 & 41 \\
\hline $26 / 5$ & 8 & 15 & $\overline{4}$ & 10 & $28 / 6$ & 97 & 38 & 42 & 39 \\
\hline $27 / 5$ & 3 & 3 & 6 & 2 & $29 / 6$ & 64 & 46 & 56 & 38 \\
\hline $28 / 5$ & 1 & 4 & 12 & 5 & $30 / 6$ & 89 & 77 & 72 & 53 \\
\hline $29 / 5$ & 6 & 3 & 7 & 2 & $01 / 7$ & 61 & 93 & 121 & 71 \\
\hline $30 / 5$ & 11 & 8 & 13 & 4 & $02 / 7$ & 74 & 62 & 35 & 21 \\
\hline $31 / 5$ & 17 & 17 & 18 & 5 & $03 / 7$ & 119 & 60 & 34 & 30 \\
\hline $01 / 6$ & 12 & 37 & 9 & 10 & $04 / 7$ & 109 & 90 & 101 & 47 \\
\hline $02 / 6$ & 69 & 66 & 34 & 30 & $05 / 7$ & 69 & 43 & 32 & 39 \\
\hline $03 / 6$ & 10 & 17 & 21 & 5 & $06 / 7$ & 18 & 33 & $\underline{36}$ & 24 \\
\hline $04 / 6$ & 1 & 10 & 5 & 2 & $07 / 7$ & 18 & 9 & $\overline{10}$ & 20 \\
\hline $05 / 6$ & 7 & 7 & 6 & 2 & $08 / 7$ & 13 & 13 & 8 & 12 \\
\hline $06 / 6$ & 18 & 8 & 17 & 4 & $09 / 7$ & 25 & 25 & 10 & 31 \\
\hline $07 / 6$ & 30 & 18 & 15 & 10 & $10 / 7$ & 10 & 7 & 7 & 9 \\
\hline $08 / 6$ & 41 & 23 & 40 & - & $11 / 7$ & 24 & 17 & 4 & 22 \\
\hline $09 / 6$ & 29 & 12 & 37 & - & $12 / 7$ & 26 & 13 & 11 & 12 \\
\hline $10 / 6$ & 6 & 33 & 49 & - & $13 / 7$ & 32 & 13 & 11 & 19 \\
\hline $11 / 6$ & 12 & 7 & 20 & - & $14 / 7$ & 14 & 16 & 23 & 21 \\
\hline $12 / 6$ & 6 & 2 & 9 & - & $15 / 7$ & 22 & 15 & 13 & 9 \\
\hline $13 / 6$ & 45 & 102 & 164 & - & $16 / 7$ & 13 & 14 & 12 & 9 \\
\hline $14 / 6$ & 74 & 77 & 125 & - & $17 / 7$ & 18 & 9 & 12 & 4 \\
\hline $15 / 6$ & 19 & 39 & 57 & 20 & $18 / 7$ & 0 & 1 & 3 & 3 \\
\hline $16 / 6$ & 29 & 19 & 111 & 26 & $19 / 7$ & 6 & 5 & 3 & 5 \\
\hline $17 / 6$ & 121 & 36 & 237 & 142 & $20 / 7$ & 1 & - & 2 & 5 \\
\hline $18 / 6$ & 27 & 39 & 86 & 74 & $21 / 7$ & 4 & - & 5 & 4 \\
\hline $19 / 6$ & 12 & 17 & 11 & 23 & $22 / 7$ & 3 & - & 0 & 5 \\
\hline $20 / 6$ & 60 & 28 & 141 & 97 & $23 / 7$ & 1 & - & 0 & 5 \\
\hline $21 / 6$ & 99 & 50 & 32 & 39 & $24 / 7$ & 5 & - & 1 & 3 \\
\hline $22 / 6$ & 107 & 63 & 60 & 74 & $25 / 7$ & 4 & - & 1 & 3 \\
\hline $23 / 6$ & 51 & 58 & 94 & 94 & $26 / 7$ & 6 & - & 5 & 7 \\
\hline $24 / 6$ & 99 & 60 & 37 & 43 & $27 / 7$ & 0 & - & 5 & 5 \\
\hline $25 / 6$ & 107 & 82 & 126 & 39 & $28 / 7$ & 7 & 4 & 2 & 8 \\
\hline \multirow[t]{3}{*}{$26 / 6$} & 155 & 66 & 76 & 63 & $29 / 7$ & 7 & 7 & 15 & 8 \\
\hline & & & & & SUM & 2373 & 1799 & 2421 & 1461 \\
\hline & & & & & & & $\begin{array}{r}\text { Rundhøj } \\
\text { skolen }\end{array}$ & $\begin{array}{r}\text { TV2- } \\
\text { Østjylland }\end{array}$ & $\begin{array}{r}\text { Aarhus } \\
\text { centre }\end{array}$ \\
\hline \multicolumn{7}{|c|}{ Correlation with the operational trap in Viborg (all data in season) } & 0.76 & 0.61 & 0.70 \\
\hline \multicolumn{7}{|c|}{ Correlation with the operational trap in Viborg (above 50 grains $\mathrm{m}^{-3}$ ) } & -0.35 & 0.15 & 0.06 \\
\hline \multicolumn{7}{|c|}{ Correlation with the operational trap in Viborg (up to 50 grains $\mathrm{m}^{-3}$ ) } & 0.68 & 0.74 & 0.88 \\
\hline
\end{tabular}

\subsection{The gridded grass pollen map with main flowering regions}

The gridded map of grass pollen source areas (Fig. 8) shows a number of hot spots in the periphery of the urban area. It also shows that one of these hot spots (density 88-100\% grass pollen areas) is located within a few hundred metres of the station TV2-Østjylland to the west and north-west.
Throughout the entire urban area a number of long and narrow areas are seen with low density (1-48\%). Few source areas are seen in the absolute vicinity of the station at Rundhøjskolen, but numerous diffuse sources are seen to the east. A number of pollen sources usually with a medium density $(14-67 \%)$ but also with a high density (88-100\%) are found 500-1500 m west of the station in central Aarhus, and almost no sources are found in other directions. The actual 
Table 2. Error matrix associated with the NDVI analysis (Fig. 3) of the Quickbird images covering the Aarhus area. User accuracy (User acc.) and Producer accuracy (Prod acc.) are based on standard methodologies according to Lillesand and Kiefer (2007).

\begin{tabular}{lrrrrrrr}
\hline \multicolumn{7}{c}{ Reference Data } \\
\hline $\begin{array}{l}\text { Classification } \\
\text { Data }\end{array}$ & Grass & Buildings & Lakes & Streets & Trees & Sum & User acc. \\
\hline Grass & $\mathbf{1 2 9}$ & 2 & 1 & 9 & 25 & 166 & $78 \%$ \\
Buildings & 1 & $\mathbf{2 5}$ & 0 & 1 & 0 & 27 & $93 \%$ \\
Lakes & 0 & 0 & $\mathbf{3}$ & 0 & 0 & 3 & $100 \%$ \\
Streets & 0 & 1 & 0 & $\mathbf{2 5}$ & 0 & 26 & $96 \%$ \\
Trees & 3 & 0 & 0 & 1 & $\mathbf{4 1}$ & 45 & $91 \%$ \\
Sum & 133 & 28 & 4 & 36 & 66 & $\mathbf{2 6 7}$ & \\
Prod acc. & $97 \%$ & $89 \%$ & $75 \%$ & $69 \%$ & $62 \%$ & & $84 \%$ \\
\hline
\end{tabular}
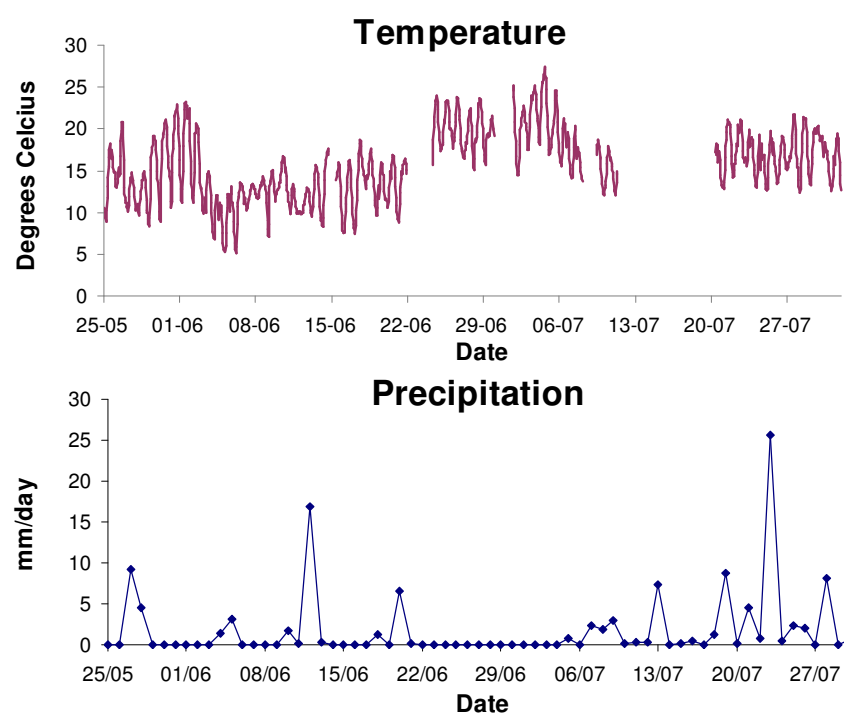

Wind direction

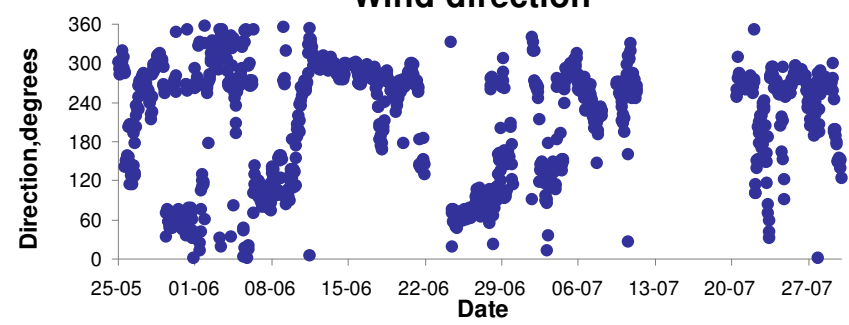

Fig. 6. Meteorological observations of temperature, precipitation and wind direction at the ENVS, AU monitoring site in central Aarhus.

data set is available in the form of a tiff file as supporting information to this article.

\section{Discussion and conclusion}

The current experiments support the hypothesis that there are large intra-urban variations in the pollen load and that such variations are connected to the source distribution on a local scale.

The highest pollen load is found together with the highest frequency of local sources, and this is observed in the surroundings of the northern trap: TV2-Østjylland (Table 1 and Fig. 8). This result is further supported by the wind direction analysis. Fifty-five percent of the peak days at the TV2Østjylland station (Fig. 7b) are found when winds are coming from the direction of the high density emission area (Fig. 8), a few hundred metres from the trap. Such a clear pattern of peak days with air masses from only one wind direction is not seen for the two other stations (Fig. 7c and d). These two stations do not have high-emitting areas in their near vicinity (Fig. 8). There was a high correlation between the daily pollen counts at each of the three stations and the operational trap in Viborg during the entire pollen season (Table 1). However, at the same time there was a lack of correlation between the stations on days with elevated pollen counts (Table 1). This suggests that on days with high load, the proximity to local emission sources is very important (Fig. 1).

Analysis of the NDVI map (Fig. 3) shows a high frequency of potential pollen sources almost everywhere except lakes, forest and the city core. This suggests that it is possible to find grass pollen sources almost everywhere. However, only a limited number of all these grass areas will contain grass areas that reach maturity and flower. The flowering of grass is determined by management of the areas. The management map here is based on the assumption that at least 2 cuts of grass areas per month are enough to prevent flowering. In Denmark, it typically takes between 15 days (Poa trivialis, Lolium multiflorum, Poa pratensis, Festuca pratensis and Lolium perenne) and up to 20 days (Phleum pratense, Dactylis glomerata and Festuca rubra) for typical Danish grass species to evolve from immature flowers into the stage of full flowering. This information is provided through the management plans that are available for Denmark and in particular Danish agriculture (e.g. http://www.dlf.dk/upload/microsoft_word_-_fr_gr_ ssernes_blomstring_og_modning.pdf). It is, however, likely 


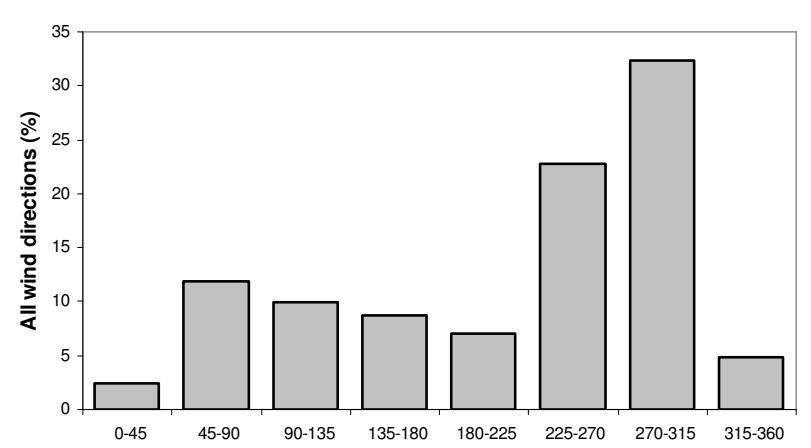

(a)

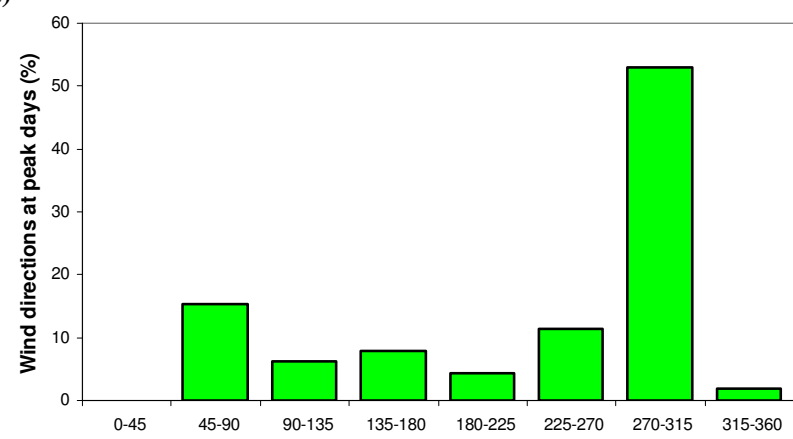

(b)

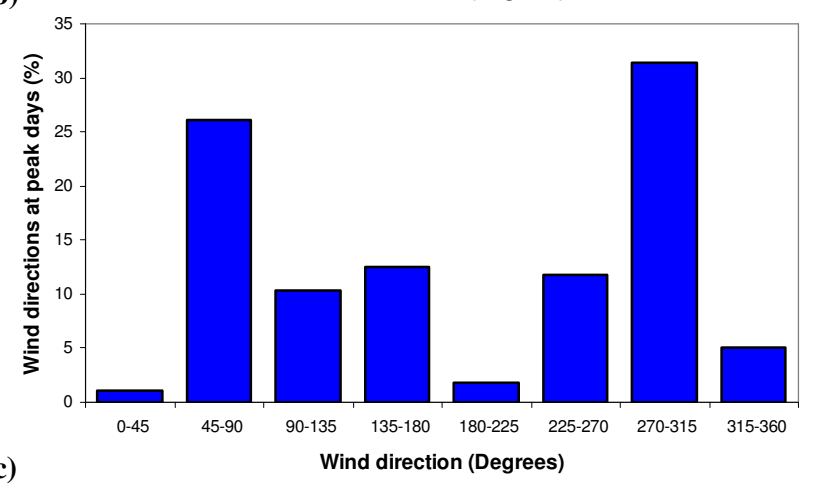

(c)

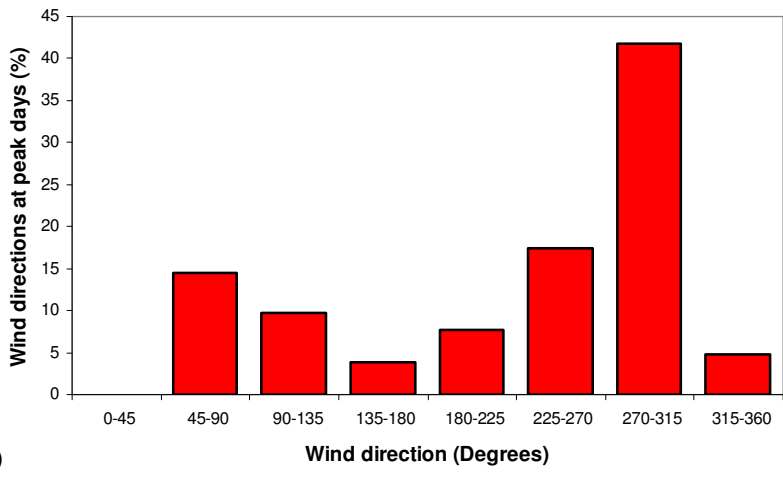

(d)

Fig. 7. (a) Percentage of all wind directions measured at the trap in central Aarhus $(n=1224)$ from different directions $\left(45^{\circ}\right.$ angles). (b) Percentage of all wind directions measured at the trap in central Aarhus $(n=255)$ from different directions $\left(45^{\circ}\right.$ angles) that were measured at peak days at TV2-Øst. (c) Percentage of all wind directions measured at the trap in central Aarhus $(n=256)$ from different directions $\left(45^{\circ}\right.$ angles) that were measured at peak days at Rundhøjskolen. (d) Percentage of all wind directions measured at the trap in central Aarhus $(n=103)$ from different directions $\left(45^{\circ}\right.$ angles) that were measured at peak days at the station in Central Aarhus. Peak days are those when the daily average Poaceae pollen counts exceed 50 grains $\mathrm{m}^{-3}$. Note that the scales on the $y$-axis are not identical in all four figures. that not all areas are strictly managed according to the management plan, and special meteorological conditions are likely to advance grass growth and maturation so that small grass areas are able to enter the flowering phase. However, the general picture is that the majority of the managed areas do not release large fractions of grass pollen, especially if they are compared to non-managed areas. The combined use of the management map (Fig. 4) and NDVI map (Fig. 3) indicates areas with a large fraction of flowering in unmanaged agricultural or urban land and a number of areas along roads, etc. These areas with potential flowering grasses are unevenly distributed throughout the urban area. This finding suggests that throughout the city a number of areas contain large gradients in the pollen concentrations - in accordance with our hypothesis.

The pollen observations are urban background concentrations. These measurements are obtained $10-20 \mathrm{~m}$ above ground level. However, according to traditional meteorological dispersion theories (Fig. 1), the pollen concentrations will be much higher near the surface when the source is located here. This, in connection with the pollen source map, suggests that elevated concentrations can be found near areas at low height, such as along the large roads seen in Fig. 8 which adds further support to the hypothesis.

The results also indicate that urban sources should not be considered exclusively. The results show that peak concentrations at the central Aarhus station (Fig. 7c) are observed during easterly winds, despite the fact that the pollen source map (Fig. 8) and the NDVI map (Fig. 3) both suggest that there are no sources in that direction. The nearest sources are about $20-60 \mathrm{~km}$ away. This again suggests that either regional-scale or long-range transport of grass pollen can be relevant. The latter is supported by a study of Smith et al. (2005), which shows that grass pollen could originate from sources more than $100 \mathrm{~km}$ away. Another study by Smith et al. (2008) adds to this finding that long-range transport is seen only episodically for species such as ragweed (Ambrosia). It is therefore likely that a strong signal from long-range transport of grass pollen, which has a much larger settling velocity than ragweed (Ambrosia), is even less frequent than for Ambrosia. Instead shorter distances are likely to be the relevant scales for grass pollen. According to the definition by Orlanski (1975), the typical distances for mesoscale atmospheric transport can be divided in three groups: meso-gamma $(2-20 \mathrm{~km})$, meso-beta $(20$ $200 \mathrm{~km}$ ) and meso-alfa (200-2000 km), where the latter covers long-distance transport. This study in combination with the existing studies on long-distance transport (e.g. Smith et al., 2008) suggests that the majority of the signal for grass pollen consists of a mixture of atmospheric transport processes on a micro- (below $2 \mathrm{~km}$ ), meso-gamma and mesobeta scale. From a modelling point of view, this has been identified as one of the major challenges to understand and describe with respect to airborne pollen transport (Sofiev et al., 2013). This highlights the importance of studying local 


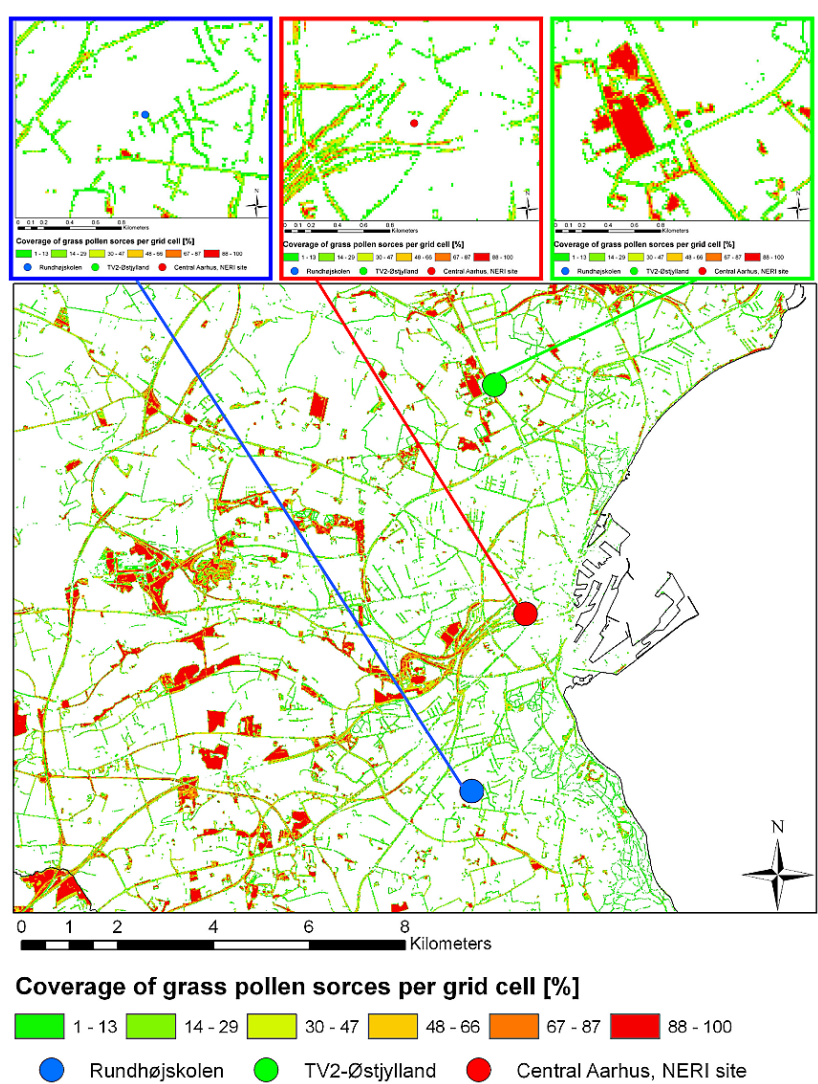

Fig. 8. Inventory of high-emitting grass pollen areas in the city of Aarhus (below) and zoom (top) that provides the vicinity of the three pollen monitoring stations.

sources and also supports our hypothesis about urban gradients in grass pollen concentrations.

The NDVI map (Fig. 3) suggests that the central urban area, forest and lake districts contain very few areas covered by grass, while all other areas could contain large grass pollen source areas. For Denmark these areas are mainly agricultural areas. About two-thirds of Danish land area is used for agriculture (Skjøth et al., 2008a), which in national and international land cover databases such as CLC2000 (European Commission, 2005) is typically indicated as agricultural land. The agricultural register data here show that most of these potential source areas are likely not to be grass pollen sources, as the majority of these areas are used for grown crops without flowering or for permanent grass which is frequently cut or grazed. Only a small fraction of the agricultural areas (fallow, rye, grass seedling) contains significant amounts of grass pollen sources, and according to Figure 4 these areas are unevenly distributed. On the regional scale, these areas are likely to be important for the overall grass pollen level in the region. It is known that management of the agricultural land is generally unevenly distributed on the regional scale (Skjøth et al., 2008a), suggesting that land cover databases such as CLC2000 or GLC2000 (Fritz et al., 2003) or other similar remote sensing products are less suitable as a stand-alone product for identifying these grass pollen source areas. Information about management of these grass covered areas need also to be included for such an identification to be of value. An alternative procedure is the collection of a series of high resolution remote sensing images taken during the entire vegetation period. This will enable mapping of land use and land cover at very high spatial resolution. Such a series of images is usually not available from satellites with high spatial resolution images, such as those from Quickbird. Therefore, series of images must be obtained using other methods such as airplanes, which increases the costs significantly. The most cost-effective solution for producing a grass pollen source inventories seems therefore to be a combination of a high resolution remote sensing images and information concerning the local management of the grass areas in the studied domain.

Clinical exposure studies of grass pollen often use concentrations in the range 1000-8000 grains $\mathrm{m}^{-3}$ (Day et al., 2006) - about a factor of 10 larger than what is found in typical peak observations. These levels are chosen to obtain a clear signal from the patients used in the exposure studies. Despite such high concentrations generally not being observed at the stations (Emberlin et al., 1999, 2000; Pashley et al., 2009; Sommer and Rasmussen, 2009), most hay fever patients have severe symptoms from grass pollen allergy every year. However, the observations are obtained at the urban background level at about 10 to $20 \mathrm{~m}$ above ground level, and according to traditional dispersion theory in meteorology the concentrations can be much higher at the surface, where people are exposed (e.g. Fig. 1). This is supported by the experiments of Rantio-Lehtmiaki et al. (1991), which show that surface concentrations can be about a magnitude larger than rooftop concentrations. This indicates that there is a large knowledge gap regarding how to link actual observations at rooftop level, symptoms among patients and findings in actual exposure studies. Model simulations of exposure to grass pollen near the surface are considered here a method of reducing this knowledge gap. Such simulations can be done by using local-scale dispersion models. A basic requirement for such studies is access to a highly detailed inventory, such as the one we present in this study (data in supplementary material), as well as verifying observations (Table 1).

This study extends a few other local-scale studies such as the one by Bricchi et al. (2000). They suggest that high gradients in London plane (Platanus) pollen are present in the city of Perugia (Italy) and that the zone of influence for single sources is less than $800 \mathrm{~m}$. Grass pollen is released at a much lower height than pollen from London plane (Platanus), and as a consequence the influence zone can be expected to be much smaller - in a similar manner as seen in Fig. 1. Urban areas have been shown to contain a significant amount of green areas, which all have the potential to be pollen sources (Pauleit et al., 2002). The composition of the green areas is, however, different between the areas, between 
cities and between regions (Pauleit and Duhme, 2000a, b). Specific considerations must therefore be taken in urbanscale experiments. Here an urban grass pollen source map is suggested, which to the knowledge of the authors has not previously been performed. This study suggests that localscale studies of pollen concentrations can be necessary and that the need for these studies depends on the presence or absence of local sources. This information can be obtained by using a combination of remote sensing and management information of the area. Other studies have used tools such as trajectory models (Cecchi et al., 2007; Skjøth et al., 2009; Stach et al., 2007) or regional-scale dispersion models (Helbig et al., 2004; Skjøth, 2009; Sofiev et al., 2006a; Zink et al., 2012). Such tools can be very useful for establishing sourcereceptor relationships on regional-scale transport. However, for local-scale sources the use of regional-scale models is less appropriate and should be based on local-scale dispersion models such as AERMOD (US-EPA, 2003) or OML (Olesen et al., 1992; Sommer et al., 2009), provided that they can be further developed to describe atmospheric dispersion of pollen. In general this requires validated phenological models and a model that parameterises daily pollen release (e.g. Skjøth et al., 2010). Emission models for use by OML that take into account crop and grass growth are already developed for Danish land area (e.g. Skjøth et al., 2004; Gyldenkærne et al., 2005; Sommer et al., 2009; Geels et al., 2012). It has previously been shown that these emission models can be extended to tree pollen (Skjøth et al., 2009, 2010). It is therefore likely that they can also be extended to grass pollen in order to handle the main grass species, such as Poa trivialis, Lolium multiflorum, Poa pratensis, Festuca pratensis, Lolium perenne, Phleum pratense, Dactylis glomerata and Festuca rubra, and in particular their flowering. The use of these models has the potential to give further insight into urban-scale concentrations in the grass pollen load, given that source inventories such as the one in Fig. 8 are available for the model applications.

Inventories such as the one given in Fig. 8 can in principle not be validated, as all data are supposed to be used by the inventory (Simpson et al., 1999; Skjøth et al., 2008a). Instead the validity behind the principles and design of these source inventories should be discussed, and if possible the quality of the inventory and its sensitivity to input data should be assessed using other methods, such as cross validation (Skjøth et al., 2010). In the study presented in this paper, the inventory depends on two data sources: a remote sensing product (Fig. 3) from the Quickbird satellite and a management map (Fig. 4). In general, the remote sensing product can be considered state-of-the-art with respect to satellite observations. Quickbird has four spectral bands, as does the Landsat7 satellite. Landsat is used for the Corine 2000 product with $100 \mathrm{~m}$ resolution (European Commission, 2005). Quickbird has a resolution several orders of magnitude higher than the Landsat7 satellite, and this makes it suitable for urban-scale studies and identification of both large and small grass areas. The
NDVI methodology does not distinguish between grass areas and other non-wooded vegetation. This means that the weeds will be misclassified as grass, thus posing a risk for overestimating the abundance of grass areas in the inventory. Nevertheless, the quality of the NDVI map must be considered very high as the overall accuracy exceeds newly released remote sensing products such as the Globcover data set (Bicheron et al., 2008). The NVDI analysis (Fig. 3) furthermore shows that only few grass areas will be located in forest areas. Such areas must be considered unmanaged, but are not considered in the potential flowering map (Fig. 4) as a result of the applied generalised forest cover. However, due to the surrounding forest, it can be assumed that the majority of the pollen from these limited areas will be trapped inside the forest canopy and therefore to a great extent will not be dispersed further into the atmosphere. This is therefore not considered a significant error in the inventory.

The map of potential flowering areas shown in Fig. 4 does not include grass along small agricultural roads between fields, nor does it include field boundaries. This introduces a risk for a small underestimation of the grass pollen areas in the rural areas. Whether it is important for the regionalscale load is not known. However, it is not considered relevant for the main hypothesis of this paper concerning sources and variations in the pollen concentration in the urban area. The map of potential flowering areas (Fig. 4) is based on exact data in combination with assumptions concerning the urban management of private areas. Particularly, one of these assumptions is questionable: Race courses and motor-cross areas are excluded on a regular basis. At least two such areas exist in the urban area of Aarhus. It is known that parts of these areas are managed, but it is likely that this assumption only applies to parts of them, meaning that some fractions of these areas are managed and others are not. This information is, however, not available for our analysis. A better map would be obtained if exact management data for these areas were available, but currently this is not the case, and it is questionable whether a complete survey among all private and public land owners would be rewarded by a significant improvement in the data quality compared to the costs of such a survey.

The analysis is also limited by equipment failures, including trap failures as well as missing data from the meteorological station. However, at least three traps out of four were working each day, so these failures are of minor importance with respect to identifying variations in the daily pollen load. The lack of meteorological data is not critical in this context either. The main period of data loss was 11-20 July; and since this period did not contain any peak days, the data loss does not affect the analysis in Fig. 7b, c and d.

The geographical coverage of the inventory is $20 \mathrm{~km} \times 20 \mathrm{~km}$ (Fig. 8). Faegri and Iversen (1992) as well as Avolio et al. (2008) suggest that the typical transport distance for pollen is in the range of $30-100 \mathrm{~km}$. This is, however, an overall estimate related to pollen from trees, 
weeds, and grasses. Pollen from trees has in general a much longer transport distance than pollen from weeds, due solely to the high release height (e.g. Fig. 1). It is therefore reasonable to assume that the inventory will capture most of the sources that contribute to the pollen load in the Aarhus area. This is furthermore supported by the studies by Bricchi et al. (2000) suggesting that the influence zone for individual sources is less than $800 \mathrm{~m}$. Nevertheless, it should be expected that long-range transport episodes will occur. Such episodes can be systematic from specific locations (Stach et al., 2007) with repeating episodes (Skjøth et al., 2007). But long-range transport is generally episodic (Belmonte et al., 2008; Smith et al., 2005, 2008). As such, it is reasonable to assume that the inventory can be used to explain the majority of local variations in the grass pollen load.

\section{Further work}

In summary and in compliance with the main hypothesis outlined in the beginning of this paper, the current study identified a number of urban grass pollen source areas. The performed analyses show that these source areas can be expected to contribute significantly to elevated grass pollen concentrations in the urban area, especially when peak concentrations are observed. Therefore it is crucial to include urban area sources in assessments and forecasts of pollen concentrations. The present study is, to the knowledge of the authors, the first published urban-scale grass pollen study which includes an integrated approach in the construction of an actual inventory of grass pollen flowering areas. The applied methodology is novel and uses available remote sensing and land use information. It also shows that the management of the grass areas (Fig. 4) is critical information in order to obtain an inventory for grass pollen source areas. Remote sensing or land cover information cannot stand alone in such an analysis. The next step will be to further develop a localscale dispersion model, such as the OML or AERMOD models (Sommer et al., 2009; US-EPA, 2003), in order to apply the pollen emission inventory, and use this as a basis for understanding and explaining air movements transporting grass pollen on the local scale. This improved understanding can be used to develop an integrated urban-scale exposure system for co-exposure of allergenic pollen and chemical air pollutants as well as chemical reactions between allergenic pollen and air pollutants. Such an integrated methodology is stateof-the-art and has previously been used in air pollution and cohort studies (Hertel et al., 2006; Sorensen et al., 2003). It is believed that this methodology can be extended to allergenic pollen (Skjøth, 2009) by combining regional-scale models like SILAM (Sofiev et al., 2006a, b) or DEHM (Brandt et al., 2012) with local-scale models like OML or AERMOD in a similar way as applied in the DAMOS system (Geels et al., 2012) - by taking variations in pollen productivity into account (Brostrom et al., 2008) at the species level as well as in the flowering pattern of the main grass species. The applied methodology behind DAMOS has proven highly useful in the assessment of air pollutants for which it is crucial to account for sources that contribute as a result of atmospheric flow pattern on a micro-, meso-gamma and meso-beta scale (Hertel et al., 2013) (in this context see the highly useful definitions of micro-, meso-gamma, and meso-beta scale in Orlanski, 1975). This methodology therefore defines the strategy to explain how various levels of pollen concentrations affect the Danish population - connections that so far have been difficult to explain (Carracedo-Martinez et al., 2008; WHO, 2003).

\section{Supplementary material related to this article is

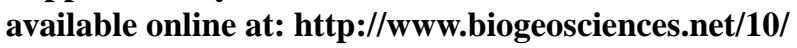 541/2013/bg-10-541-2013-supplement.zip.}

Acknowledgements. This work was partly funded by the Aarhus University Research Foundation as a part of the A3 research centre and an individual post doc grant from the VKR-Foundation to Carsten Ambelas Skjøth. TV2-Østjylland and Rundhøjskolen are acknowledged for allowing continuous pollen monitoring on their roofs and for supplying facilities. The Tuborg Foundation is acknowledged for providing a number of pollen traps for research purposes and as a basis for improved information to the public. Finally the work includes measured meteorological observations that are performed within the nationwide Air Quality Monitoring Programme for urban areas (LMP), and especially Thomas Ellermann is highly acknowledged for providing access to these data. Technicians Bjarne Jensen and Morten Hildan at the Department of Environmental Science are acknowledged for their professional assistance with the sampling of urban pollen in Aarhus.

Edited by: X. Wang

\section{References}

Alcazar, P., Galan, C., Carinanos, P., and Dominguez-Vilches, E.: Effects of sampling height and climatic conditions in aerobiological studies, J. Invest. Allerg. Clin., 9, 253-261, 1999.

Avolio, E., Pasqualoni, L., Federico, S., Fornaciari, M., Bonofiglio, T., Orlandi, F., Bellecci, C., and Romano, B.: Correlation between large-scale atmospheric fields and the olive pollen season in Central Italy, Int. J. Biometeorol., 52, 787-796, 2008.

Belmonte, J., Alarcon, M., Avila, A., Scialabba, E., and Pino, D.: Long-range transport of beech (Fagus sylvatica L.) pollen to Catalonia (north-eastern Spain), Int. J. Biometeorol., 52, 675-687, 2008.

Bicheron, P., Defourny, P., Brockmann, C., Schouten, L., Vancutsem, C., Huc, M., Bontemps, S., Leroy, M., Achard, F., Herold, M., Ranera, F., and Arino, O.: Globcover products description Manual MEDIAS-France, 2008.

Brandt, J., Silver, J. D., Frohn, L. M., Geels, C., Gross, A., Hansen, A. B., Hansen, K. M., Hedegaard, G. B., Skjøth, C. A., Villadsen, H., Zare, A., and Christensen, J. H.: An integrated model 
study for Europe and North America using the Danish Eulerian Hemispheric Model with focus on intercontinental transport of air pollution, Atmos. Environ., 53, 156-176, 2012.

Bricchi, E., Frenguelli, G., and Mincigrucci, G.: Experimental results about Platanus pollen deposition, Aerobiologia, 16, 347352, 2000.

Brostrom, A., Nielsen, A. B., Gaillard, M. J., Hjelle, K., Mazier, F., Binney, H., Bunting, J., Fyfe, R., Meltsov, V., Poska, A., Rasanen, S., Soepboer, W., von Stedingk, H., Suutari, H., and Sugita, S.: Pollen productivity estimates of key European plant taxa for quantitative reconstruction of past vegetation: a review, Veg. Hist. Archaeobot., 17, 461-478, 2008.

Brown, H. M. and Irving, K. R.: Size and Weight of Common Allergenic Pollens - Investigation of Their Number Per Microgram and Size Distribution, Acta Allergol., 28, 132-137, 1973.

Carracedo-Martinez, E., Sanchez, C., Taracido, M., Saez, M., Jato, V., and Figueiras, A.: Effect of short-term exposure to air pollution and pollen on medical emergency calls: a case-crossover study in Spain, Allergy, 63, 347-353, 2008.

Cecchi, L., Malaspina, T., Albertini, R., Zanca, M., Ridolo, E., Usberti, I., Morabito, M., Dall' Aglio, P., and Orlandini, S.: The contribution of long-distance transport to the presence of Ambrosia pollen in central northern Italy, Aerobiologia, 23, 145$151,2007$.

Chuine, I. and Belmonte, J.: Improving prophylaxis for pollen allergies: Predicting the time course of the pollen load of the atmosphere of major allergenic plants in France and Spain, Grana, 43, 65-80, 2004.

D'amato, G., Cecchi, L., Bonini, S., Nunes, C., Annesi-Maesano, I., Behrendt, H., Liccardi, G., Popov, T., and Van Cauwenberge, P.: Allergenic pollen and pollen allergy in Europe, Allergy, 62, 976-990, 2007.

Day, J. H., Horak, F., Briscoe, M. P., Canonica, G. W., Fineman, S. M., Krug, N., Leynadier, F., Lieberman, P., Quirce, S., Takenaka, H., and Cauwenberge, P.: The role of allergen challenge chambers in the evaluation of anti-allergic medication: an international consensus paper, Clin. Exp. Allergy Rev., 6, 31-59, 2006.

DigitalGlobe Corporate: Quickbird spacecraft data sheet Longmont, Colorado, 2010.

Durham, O. C.: The Volumetric Incidence of Atmospheric Allergens, 3. Rate of Fall of Pollen Grains in Still Air, J. Allergy, 17, 70-78, 1946.

Ellermann, T., Andersen, H. V., Bossi, R., Christensen, J., Frohn, L. M., Geels, C., Kemp, K., Løfstrøm, P., Mogensen, B. B., and Monies, C.: Atmospheric Deposition 2006, NOVANA (in Danish: Atmosfærisk Deposition, NOVANA) National Environmental Research Institute, University of Aarhus, Roskilde, Denmark, 2007.

Emberlin, J., Mullins, J., Corden, J., Jones, S., Millington, W., Brooke, M., and Savage, M.: Regional variations in grass pollen seasons in the UK, long-term trends and forecast models, Clin. Exp. Allergy, 29, 347-356, 1999.

Emberlin, J., Jaeger, S., Dominguez-Vilches, E., Soldevilla, C. G., Hodal, L., Mandrioli, P., Lehtimäki, A. R., Savage, M., Spieksma, F. T., and Bartlett, C.: Temporal and geographical variations in grass pollen seasons in areas of western Europe: an analysis of season dates at sites of the European pollen information system, Aerobiologia, 16, 373-379, 2000.
European Commission: Image 2000 and CLC2000 Products and Methods European Commission, Joint Research Center (DG JRC), Institute for Environment and Sustainability, Land Management Unit, 21020 Ispra (VA), Italy, 2005.

Faegri, K. and Iversen, J.: Textbook of Pollen Analysis, John Wiley and Sons, 1992.

Fritz, S., Bartholome, E., Belward, A., Hartley, A., Stibig, H.-J., Eva, H., Mayaux, P., Bartalev, S., Latifovic, R., Kolmert, S., Roy, P. S., Agrawal, S., Bingfang, W., Wenting, X., Ledwith, M., Pekel, J.-F., Giri, C., Mücher, S., de Badts, E., Tateishi, R., Champeaux, J.-L., and Defourny, P.: The Global Land Cover for the Year 2000 European Commission, Joint Research Centre, 2003.

Fumanal, B., Chauvel, B., and Bretagnolle, F.: Estimation of pollen and seed production of common ragweed in France, Ann. Agr. Env. Med., 14, 233-236, 2007.

Garcìa-Mozo, H., Galán, C., Belmonte, J., Bermejo, D., Candau, P., Díaz de la Guardia, C., Elvira, B., Gutiérrez, M., Jato, V., Silva, I., Trigo, M. M., Valencia, R., and Chuine, I.: Predicting the start and peak dates of the Poaceae pollen season in Spain using process-based models, Agr. Forest Meteorol., 149, 256262, 2009.

Geels, C., Andersen, H. V., Ambelas Skjøth, C., Christensen, J. H., Ellermann, T., Løfstrøm, P., Gyldenkærne, S., Brandt, J., Hansen, K. M., Frohn, L. M., and Hertel, O.: Improved modelling of atmospheric ammonia over Denmark using the coupled modelling system DAMOS, Biogeosciences, 9, 2625-2647, doi:10.5194/bg-9-2625-2012, 2012.

Goldberg, C., Buch, H., Moseholm, L., and Weeke, E. R.: Airborne Pollen Records in Denmark, 1977-1986, Grana, 27, 209-217, 1988.

GRASS Development Team: Geographic Resource Analysis Support System (GRASS) Software: Open source Geospatial Foundation Project, 2008.

Gregory, P. H.: The microbiology of the Atmosphere: Aylesbury, Bucks, UK, Leonard Hill, 1973.

Gyldenkærne, S., Ambelas Skjøth, C., Hertel, O., and Ellermann, T., A dynamical ammonia emission parameterization for use in air pollution models, J. Geophys. Res., 110, D07108, doi:10.1029/2004JD005459, 2005.

Helbig, N., Vogel, B., Vogel, H., and Fiedler, F.: Numerical modelling of pollen dispersion on the regional scale, Aerobiologia, 20, 3-19, 2004.

Hertel, O., Jensen, S. S., Hvidberg, M., Ketzel, M., Berkowicz, R., Sorensen, M., Loft, S., and Nielsen, O. R.: Exposure modeling - Using operational air pollution models, Toxicol. Lett., 164S, S15-S16, 2006.

Hertel, O., Ellermann, T., Palmgren, F., Berkowicz, R., Lofstrom, P., Frohn, L. M., Geels, C., Skjoth, C. A., Brandt, J., Christensen, J., Kemp, K., and Ketzel, M.: Integrated air-quality monitoring combined use of measurements and models in monitoring programmes, Environ. Chem., 4, 65-74, 2007.

Hertel, O., Geels, C., Frohn, L. M., Ellermann, T., Skjoth, C. A., Lofstrom, P., Christensen, J. H., Andersen, H. V., and Peel, R. G.: Assessing atmospheric nitrogen deposition to natural and seminatural ecosystems - Experience from Danish studies using the DAMOS system, Atmos. Environ., 66, 151-160, 2013.

Hirst, J. M.: An automatic volumetric spore trap, Ann. Appl. Biol., 39, 257-265, 1952. 
Jato, V., Rodriguez-Rajo, F. J., Seijo, M. C., and Aira, M. J.: Poaceae pollen in Galicia (NW Spain): characterisation and recent trends in atmospheric pollen season, Int. J. Biometeorol., 53, 333-344, 2009.

Käpyla, M. and Penttinen, A.: An evaluation of the microscopial counting methods of the tape in Hirst-Burkard pollen and spore trap, Grana, 20, 131-141, 1981.

Laaidi, M.: Forecasting the start of the pollen season of Poaceae: evaluation of some methods based on meteorological factors, Int. J. Biometeorol., 45, 1-7, 2001.

Lillesand, T. M., Kiefer, R. W., and Chipman, J. W.: Remote Sensing and Image Interpretation, John Wiley \& Sons, NY, USA, 2007.

Mäkelä, E. M.: Size distinctions between Betula pollen types - A review, Grana, 35, 248-256, 1996.

Olesen, H. R., Løfstrøm, P., Berkowicz, R., and Jensen, A. B.: An Improved dispersion model for regulatory use - the OML model, Nato Chal. M, 29-38, 1992.

Orlanski, I.: A rational subdivision of scales for atmospheric processes, B. Am. Meteor. Soc. 56, 527-530, 1975.

Pashley, C., Fairs, A., Edwards, R., Bailey, J., Corden, J., and Wardlaw, A.: Reproducibility between counts of airborne allergenic pollen from two cities in the East Midlands, UK, Aerobiologia, 25, 249-263, 2009.

Pauleit, S. and Duhme, F.: Assessing the environmental performance of land cover types for urban planning, Landscape Urban Plan., 52, 1-20, 2000a.

Pauleit, S. and Duhme, F.: GIS assessment of Munich's Urban Forest structure for Urban planning, J. Arboriculture, 26, 133-141, 2000b.

Pauleit, S., Jones, N., Garcia-Martin, G., Garcia-Valdecantos, J. L., Riviere, L. M., Vidal-Beaudet, L., Bodson, M., and Randrup, T. B.: Tree establishment practice in towns and cities - Results from a European survey, Urban For. Urban Gree., 1, 83-96, 2002.

Petersen, N. and Munch, E.: Anvendelsen af aerobiologiske data, in: Pollen og Skimmelsvampesporer, Symposium om pollen og skimmelsvampesporers betydning ved allergiske sygdomme, edited by: Weeke, E. and Petersen, N. B., Scanticon, Århus, Denmark, 1981.

Pohl, F.: Die Pollenerzeugung der Windblüter, Eine vergleichende Untersuchiung mit Ausblicken auf den Bestäubungshaushalt tierblütiger Gewächse und die pollenanalytische Waldgeschichtsforshung, Beih. Bot. Centrallblatt, 56, 365-470, 1937.

Rantio-Lehtimaki, A., Koivikko, A., Kupias, R., Makinen, Y., and Pohjola, A.: Significance of Sampling Height of Airborne Particles for Aerobiological Information, Allergy, 46, 68-76, 1991.

Seinfeld, J. H. and Pandis, S. N.: Atmospheric Chemistry and Physics, John Wiley \& Sons Inc, New York, USA, 1326 pp., 1998.

Simpson, D., Winiwarter, W., Borjesson, G., Cinderby, S., Ferreiro, A., Guenther, A., Hewitt, C. N., Janson, R., Khalil, M. A. K., Owen, S., Pierce, T. E., Puxbaum, H., Shearer, M., Skiba, U., Steinbrecher, R., Tarrason, L., and Oquist, M. G.: Inventorying emissions from nature in Europe, J. Geophys. Res.-Atmos., 104, 8113-8152, 1999.

Skjøth, C. A.: Integrating measurements, phenological models and atmospheric models in Aerobiology - creating new concepts within aerobiological integrated monitoring and forecasting Fac- ulty of Science, Copenhagen University, Ph.D. thesis, 123 pp., 2009.

Skjøth, C. A., Hertel, O., Gyldenkærne, S., and Ellermann, T.: Implementing a dynamical ammonia emission parameterization in the large-scale air pollution model ACDEP, J. Geophys. Res., 109, D06306, doi:10.1029/2003JD003895, 2004.

Skjøth, C. A., Sommer, J., Stach, A., Smith, M., and Brandt, J.: The long range transport of birch (Betula) pollen from Poland and Germany causes significant pre-season concentrations in Denmark, Clin. Exp. Allergy, 37, 1204-1212, 2007.

Skjøth, C. A., Geels, C., Hvidberg, M., Hertel, O., Brandt, J., Frohn, L. M., Hansen, K. M., Hedegaard, G. B., Christensen, J., and Moseholm, L.: An inventory of tree species in Europe - an essential data input for air pollution modelling, Ecol. Modell., 217, 292-304, 2008a.

Skjøth, C. A., Sommer, J., Brandt, J., Hvidberg, M., Geels, C., Hansen, K., Hertel, O., Frohn, L., and Christensen, J.: Copenhagen - a significant source of birch (Betula) pollen?, Int. J. Biometeorol., 52, 453-462, 2008b.

Skjøth, C. A., Smith, M., Brandt, J., and Emberlin, J.: Are the birch trees in Southern England a source of Betula pollen for North London?, Int. J. Biometeorol., 53, 75-86, 2009.

Skjøth, C. A., Smith, M., Sikoparija, B., Stach, A., Myszkowska, D., Kasprzyk, I., Radisic, P., Stjepanovic, B., Hrga, I., Apatini, D., Magyar, D., Paldy, A., and Ianovici, N.: A method for producing airborne pollen source inventories: An example of Ambrosia (ragweed) on the Pannonian Plain, Agr. Forest Meteorol., 150, 1203-1210, 2010.

Smith, M. and Emberlin, J.: Constructing a 7-day ahead forecast model for grass pollen at north London, United Kingdom, Clin. Exp. Allergy, 35, 1400-1406, 2005.

Smith, M. and Emberlin, J.: A 30-day-ahead forecast model for grass pollen in north London, United Kingdom, Int. J. Biometeorol., 50, 233-242, 2006.

Smith, M., Emberlin, J., and Kress, A.: Examining high magnitude grass pollen episodes at Worcester, United Kingdom, using backtrajectory analysis, Aerobiologia, 21, 85-94, 2005.

Smith, M., Skjøth, C. A., Myszkowska, D., Uruska, A., Malgorzata, P., Stach, A., Balwierzg, Z., Chlopek, K., Piotrowska, K., Kasprzyk, I., and Brandt, J.: Long-range transport of Ambrosia pollen to Poland, Agr. Forest Meteorol., 148, 1402-1411, 2008.

Smith, M., Emberlin, J., Stach, A., Rantio-Lehtimaki, A., Caulton, E., Thibaudon, M., Sindt, C., Jager, S., Gehrig, R., Frenguelli, G., Jato, V., Rajo, F. J. R., Alcazar, P., and Galan, C.: Influence of the North Atlantic Oscillation on grass pollen counts in Europe, Aerobiologia, 25, 321-332, 2009.

Sofiev, M., Siljamo, P., Ranta, H., and Rantio-Lehtimaki, A.: Towards numerical forecasting of long-range air transport of birch pollen: theoretical considerations and a feasibility study, Int. J. Biometeorol., 50, 392-402, 2006a.

Sofiev, M., Siljamo, P., Valkama, I., Ilvonen, M., and Kukkonen, J.: A dispersion modelling system SILAM and its evaluation against ETEX data, Atmos. Environ., 40, 674-685, $2006 \mathrm{~b}$.

Sofiev, M., Belmonte, J., Gehrig, R., Izquierdo, R., Smith, M., Dahl, A., and Siljamo, P.: Airborne Pollen Transport, in: Allergenic Pollen: A Review of the Production, Release, Distribution and Health Impacts, edited by: Sofiev, M. and Bergmann, K.-C., Springer, The Netherlands, 127-159, doi:10.1007/978-94-0074881-1_5, 2013. 
Sommer, J. and Rasmussen, A.: Measurements of pollen and spores in Denmark 2009 (in Danish: Pollen- og sporemålinger i Danmark sæsonen 2009) The Astma-Allergy Association, Universitetsparken 4, 4000 Roskilde, Denmark, 2009.

Sommer, S. G., Østergård, H. S., Løfstrøm, P., Andersen, H. V., and Jensen, L. S.: Validation of model calculation of ammonia deposition in the neighbourhood of a poultry farm using measured $\mathrm{NH}_{3}$ concentrations and $\mathrm{N}$ deposition, Atmos. Environ., 43, 915-920, 2009.

Sorensen, M., Autrup, H., Moller, P., Hertel, O., Jensen, S. S., Vinzents, P., Knudsen, L. E., and Loft, S.: Linking exposure to environmental pollutants with biological effects, Mutat. Res.Rev. Mutat., 544, 255-271, 2003.

Stach, A., Smith, M., Skjøth, C. A., and Brandt, J.: Examining Ambrosia pollen episodes at Poznañ (Poland) using back-trajectory analysis, Int. J. Biometeorol., 51, 275-286, 2007.

Stach, A., Smith, M., Baena, J. C. P., and Emberlin, J.: Long-term and short-term forecast models for Poaceae (grass) pollen in Poznan, Poland, constructed using regression analysis, Environ. Exp. Bot., 62, 323-332, 2008.
US-EPA: AERMOD: Latest Features and Evaluation Results U.S Environmental Protection Agency, Office of AirQuality Planning and Standards, Emissions Monitoring and Analysis Division, Research Triangle Park, NC27711, USA, 2003.

Weeke, E.: Behandling af pollen- og skimmelssporeallergi, in: Pollen og Skimmelsvampesporer, Symposium om pollen og skimmelsvampesporers betydning ved allergiske sygdomme, edited by: Weeke, E. and Petersen, N. B., Scanticon, Århus, Denmark, 1981.

WHO: Phenology and Human Health: Allergic Disorders WHO Regional Office for Europe, Scherfigsvej 8, 2100, Copenhagen $\varnothing$, Denmark, 2003.

Zink, K., Vogel, H., Vogel, B., Magyar, D., and Kottmeier, C.: Modeling the dispersion of Ambrosia artemisiifolia $\mathrm{L}$. pollen with the model system COSMO-ART, Int. J. Biometeorol., 56, 669-680, doi:10.1007/s00484-011-0468-8, 2012. 